\title{
Urgensi Pendidikan Humanis Religius Pada Pendidikan Dasar Islam
}

\author{
Agus Riyan Oktori \\ Institut Agama Islam Negeri Curup \\ agusriyanoktori@iaincurup.ac.id
}

\begin{abstract}
Education does not merely promote cognitive intelligence as a person's priority to be accepted in society. The development of all children's potential is the duty of every educator to be able to create a generation that has religious and humanist values. The existence of the concept of humanizing humans need to be introduced from the first time they go through the education process, in order to present a learning process that actually opens a space for children to become creative and imaginative, and to develop their abilities optimally. Throwing away the words that weaken students and assuming them that they have failed in undergoing the educational process becomes an important point of the concept of religious and humanist education. If the education process does not try to emphasize that children are the best masterpieces of educators, children need fun learning methods, children do not get discriminatory behavior from educators, then it will be very likely that the time will bring education to a much better change going forward. In particular, Islamic basic education is a meaningful requirement of the concept of religious and humanist education.
\end{abstract}

Keywords: Religious humanist, Islamic basic education, Urgency

Abstrak : Pendidikan tidak semata-mata mengedepankan kecerdasan kognitif sebagai prioritas seseorang untuk bisa diterima di tengah masyarakat luas. Pengembangan seluruh potensi anak merupakan kewajiban setiap pendidik untuk bisa menghadirkan generasi yang kaya akan muatan nilai humanis religius. Perwujudan konsep memanusiakan manusia sejatinya diperkenalkan sejak awal mereka menempuh proses pendidikan demi menghadirkan proses pembelajaran yang sebenarnya membuka ruang anak berkreasi, berimajinasi, serta pengembangan kemampuan diri secara optimal. Membuang jauh lontaran perkataan yang melemahkan anak, dan anggapan bahwa mereka telah gagal dalam menjalani proses pendidikan menjadi poin penting dari konsep pendidikan humanis religius. Apabila proses pendidikan tidak berusaha mengedepankan bahwa anak merupakan mahakarya terbaik seorang pendidik, anak memerlukan metode pembelajaran yang menyenangkan, anak tidak mendapat perilaku diskriminatif dari pendidik, maka sangat mungkin putaran waktu akan membawa pendidikan pada perubahan

AR-RIAYAH : Jurnal Pendidikan Dasar vol. 3, no. 2, 2019

IAIN Curup - Bengkulu| pISSN2580-362X; eISSN2580-3611

http://journal.iaincurup.ac.id/index.php/JPD 
yang jauh lebih baik kedepannya. Khususnya, pendidikan dasar Islam yang syarat makna akan konsep pendidikan humanis religius.

Kata Kunci: Humanis Religius, Pendidikan Dasar Islam, Urgensi

\section{PENDAHULUAN}

Pendidikan merupakan sebuah langkah proses perubahan seorang individu dari sikap tidak tahu menuju titik dimana seseorang memiliki kesadaran kritis terhadap segala sesuatu yang ditemukan pada diri dan lingkungannya. Dalam hal ini, seharusnya pendidikan menjadi wadah dalam rangka menghadirkan pola pikir yang berkemajuan serta pribadi-pribadi yang memiliki potensi untuk menjadi agen perubahan pada lingkungan sosial. Pendidikan seyogyanya mampu menjadi roda penggerak untuk mengembangkan dan memaksimalkan seluruh kemampuan peserta didik agar mampu berkompetisi secara sehat pada setiap jenjangnya. ${ }^{1}$

Pendidikan memiliki interpretasi yang begitu urgen dalam melakoni proses kehidupan. Interpretasi tersebut menjadi kesepakatan yang menyeluruh dari setiap lapisan masyarakat. Kemungkinan yang sangat kecil untuk menolak, mengingkari, bahkan membungkam dari golongan masyarakat tentang arti penting dari sebuah pendidikan. ${ }^{2}$ Kualitas dan kuantitas pendidikan akan sangat berpengaruh terhadap sumber daya manusia itu sendiri. Manusia yang ada sekarang tidak akan memiliki perbedaan dengan yang ada di masa lalu terkait pengelolaan kehidupan dan pola pemberdayaan, apabila tidak memiliki kesadaran terhadap pendidikan. Peradaban yang berkembang dan berkemajuan pada masyarakat, bangsa, dan negara akan memberikan dampak yang signifikan apabila di topang oleh pendidikan yang berkualitas. ${ }^{3}$

Salah satu problematika yang sedang menghantui bahkan menjadi senjata pembunuh terbaik pada lembaga pendidikan yakni kemerosotan pada dimensi moralitas. Pendidikan seyogyanya diharapkan menjadi jalan untuk melestarikan nilai-nilai moralitas tersebut. Perkembangan perilaku yang mulai bertentangan dengan nilai pendidikan, pengaruh budaya luar yang semakin hari

1 Bambang Sugiharto (ed), Humanisme dan Humaniora: Relevansinya bagi Pendidikan, (Yogyakarta: Jala Sutra, 2008), hlm. 343 ), hlm. 17

2 As'aril Muhajir, Ilmu Pendidikan Perspektif Kontekstual (Yogyakarta:Ar-Ruzz Media,2011

3 Haryanto Al-Fandi, Desain Pembelajaran yang Demokratis dan Humanis, (Yogyakarta, ArRuzz Media, 2011), hlm. 26 
menjadi dominasi prioritas di kalangan pelajar, serta perkembangan teknologi yang perlahan mulai menyentuh masyarakat pedesaan. Perlahan namun pasti, semua tergerus dan bergeser setiap waktunya memudarkan muatan nilai-nilai moralitas yang menjadi identitas bangsa.

Kritikan paling mendasar terhadap realitas pendidikan adalah semakin kaburnya keberadaan dunia pendidikan terhadap nilai-nilai kemanusiaan. Semakin hari, suasana dehumanistis semakin menguasai tindakan peserta didik. Nilai-nilai kasih sayang, rasa kebersamaan, sikap jujur, pribadi yang pekerja keras semakin terpinggirkan. Salah satu faktor yang menyebabkannya yakni lebih mengedepankan aspek kognitif. Keberhasilan seseorang pada dunia pendidikan selalu di ukur oleh angka pada setiap proses ujian. Seharusnya, berhasil atau tidaknya seseorang harus terukur dari seluruh aspek pembelajaran yang sudah ditentukan. ${ }^{4}$

Penguatan dan pembiasaan dalam rangka menginternalisasikan nilai-nilai berbasis humanis religius harus di mulai dari tahapan pendidikan dasar, bahkan usia dini. Hal tersebut dilakukan dalam rangka meminimalisir munculnya kepribadian-kepribadian peserta didik yang jauh dari nilai keagamaan. Ruang lingkup materi serta kegiatan yang akan dilakukan, setidaknya harus mengandung muatan nilai humanis religius tersebut. Oleh sebab itu, kita akan mempelajari dan memahami sejauh mana urgensi dan esensi dari sebuah proses pendidikan Islam pada level dasar dengan memasukkan muatan-muatan nilai humanis religius dalam rangka menghasilkan dan mewujudkan generasi-generasi peserta didik yang kaya akan kepribadian yang lebih baik.

\section{PEMBAHASAN}

\section{Kajian Konseptual Pendidikan Perspektif Islam}

Pendidikan Islam merupakan pendidikan yang dilakukan sesuai dengan ajaran dalam Islam. Ajaran yang berdasarkan Alqur'an, hadist, pandangan para ulama, serta warisan dari sejarah. Untuk melihat perbedaannya dengan pendidikan lain, ajaran Islam menggunakan cara berpikir rasional dan empiris, namun tetap berdasarkan Alqur'an dan hadist. Sementara pendidikan yang lain, lebih kepada berpikir rasional dan impristik saja. ${ }^{5}$ Dasar pelaksanaan pendidikan Islam merujuk pada firman Allah dalam surat Asy-Syura ayat 52: 


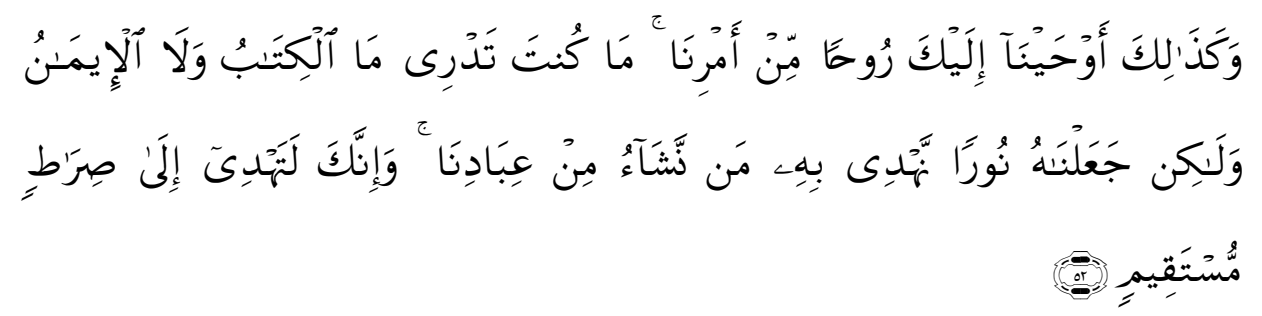

Artinya: "dan Demikianlah Kami wahyukan kepadamu wahyu (Al Quran) dengan perintah kami. sebelumnya kamu tidaklah mengetahui Apakah Al kitab (Al Quran) dan tidak pula mengetahui Apakah iman itu, tetapi Kami menjadikan Al Quran itu cahaya, yang Kami tunjuki dengan Dia siapa yang Kami kehendaki di antara hamba-hamba kami. dan Sesungguhnya kamu benar- benar memberi petunjuk kepada jalan yang lurus. ${ }^{6}$

Adapun dalam bahasa Arab istilah pendidikan yang sering dipakai yakni at-ta'lim. Definisi at-ta'lim ${ }^{7}$ dalam perspektif Dedeng Rasyidin yakni berhubungan dengan informasi, yaitu pada aspek kognitif dan juga aspek keterampilan. Tujuan dari at-ta'lim adalah untuk mendapatkan pengetahuan, pengalaman serta pemahaman terhadap suatu ilmu. At'ta'lim juga merupakan penyampaian dan pemaparan mengenai sesuatu yang terdiri dari isi dan tujuan yang disampaikan secara bertahap, berkelanjutan, metode yang mudah di mengerti, mengedepankan adab, serta berkasih sayang. ${ }^{8}$

Istilah lain yang juga sering digunakan yakni al-Tarbiyah. Interpretasi dari kata al-Tarbiyah sendiri adalah suatu usaha dalam menumbuhkembangkan serta mewujudkan kematangan peserta didik, baik dari aspek jasmani, rohani, sosial, serta spiritual. Selain itu, al-Tarbiyah juga bisa diterjemahkan sebagai kegiatan mentransformasikan ilmu pengetahuan kepada anak agara mampu memiliki perilaku baik, serta spirit yang kuat

6 Al-Qur ${ }^{e} a n$ dan Terjemahannya Dilengkapi Kajian Ushul Fighi, (Jakarta: Departemen Agama, 2007).

7 Al-Ta'lim merupakan kata benda buatan (mashdar) yang berasal dari akar kata 'allama. Istilah tarbiyah diterjemahkan dengan pendidikan, sedangkan ta'lim diterjemahkan dengan pengajaran. Menurut Rasyid Ridha dalam Tafsir Al-Manar yang dikutip Ramayulis, ta'lim adalah proses transmisi berbagai ilmu pengetahuan pada jiwa individu tanpa adanya batasan dan ketentuan tertentu. Kemudian, dalam kesempatan yang lain Al-Maraghi menyatakan bahwa atta'lim adalah pengajaran yang dilaksanakan secara bertahap, sebagaimana tahapan Nabi Adam mempelajari, menyaksikan, dan menganalisa asma-asma yang diajarkan Allah kepadanya. Ini berarti at'ta'lim mencakup kognitif belaka, belum mencapai domain lainnya. Lihat buku Ahmad Izzan dan Saehuddin, Tafsir Pendidikan: Studi Ayat-Ayat Berdimensi Pendidikan, Jakarta: Pustaka Aufa Media, 2012) hlm. 2

8 Ahmad Izzan dan Saehudin, Tafsir Pendidikan: Studi Ayat-Ayat Berdimensi Pendidikan, (Jakarta: Pustaka Aufa Media, 2012), hlm. 2 
dalam memaknai proses kehidupan. Pemaknaan pendidikan dalam Alqur'an tidak hanya merujuk pada pengembangan kecerdasan intelektual saja, aspek sikap pun harus mampu dilaksanakan dalam kehidupan sehari-hari.' Sebagaimana dapat kita lihat dalam Alqur'an dalam Q.S Al-Isra:24 yang berbunyi:

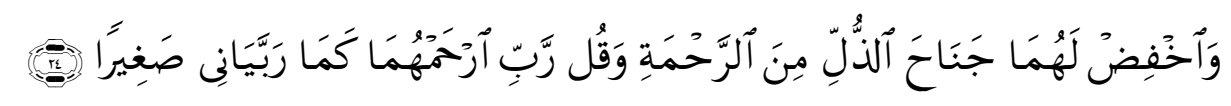

Artinya: dan rendahkanlah dirimu terhadap mereka berdua dengan penuh kesayangan dan ucapkanlah: "Wahai Tuhanku, kasihilah mereka keduanya, sebagaimana mereka berdua telah mendidik aku waktu kecil". ${ }^{10}$

Perbincangan mengenai pendidikan Islam dalam konteks Indonesia, tak akan luput dari ideologi bangsa Indonesia sendiri, yakni Pancasila. Semboyan "Berbeda Namun Tetap Satu" apabila dihubungkan dengan pemahaman dalam Islam, bahwa manusia didefinisikan sebagai "Umatan Wabidah atau umat yang satu. Pendidikan Islam memiliki harapan besar untuk menjadi rahmat seluruh dan mampu menutup ruang fanatisme buta yang berujung paham radikal. Tindakan yang memicu pertengkaran, perpecahan, serta permusuhan berusaha di antisipasi sebaik mungkin untuk

9 Abdul Mujib dan Jusuf Mudzakkir, Ilmu Pendidikan Islam: Pengantar ke Arah Ilmu Pendidikan Islam, (Jakarta: Kencana, 2006), hlm. 13

10 Al-Qur an dan Terjemahannya Dilengkapi Kajian Ushul Fighi, (Jakarta: Departemen Agama, 2007).

11 Bhinneka Tunggal Ika adalah moto atau semboyan bangsa Indonesia yang tertulis pada lambang negara Indonesia, Garuda Pancasila. Frasa ini berasal dari bahasa Jawa Kuno yang artinya "Berbeda-beda tetapi tetap satu". Secara etimologis, kata bhinneka berarti "beraneka ragam". Kata neka dalam bahasa Sanskerta berarti "macam" dan menjadi pembentuk kata "aneka" dalam Bahasa Indonesia. Kata tunggal berarti "satu". Kata ika berarti "itu". Secara harfiah Bhinneka Tunggal Ika diterjemahkan "Beraneka Satu Itu”, yang bermakna meskipun beranekaragam tetapi pada hakikatnya bangsa Indonesia tetap adalah satu kesatuan. Semboyan ini digunakan untuk menggambarkan persatuan dan kesatuan Bangsa dan Negara Kesatuan Republik Indonesia yang terdiri atas beraneka ragam budaya, bahasa daerah, ras, suku bangsa, agama dan kepercayaan. alimat Bhinneka Tunggal Ika merupakan kutipan dari sebuah kakawin Jawa Kuno yaitu kakawin atau kitab Sutasoma, karangan Mpu Tantular semasa kerajaan Majapahit sekitar abad ke-14. Kakawin ini istimewa karena mengajarkan toleransi antara umat Hindu Siwa dengan umat Buddha. Hal ini menunjukkan persatuan dan kesatuan yang terjadi di wilayah Indonesia, dengan keberagaman penduduk Indonesia yang terdiri dari beragam suku, bahasa daerah, ras, agama, dan kepercayaan, lantas tidak membuat Indonesia menjadi terpecah belah. Melalui semboyan ini, Indonesia bisa dipersatukan dan semua keberagaman tersebut menjadi satu bagian dari Negara Kesatuan Republik Indonesia (NKRI). 
menguatkan putaran roda kehidupan yang rukun diantara umat beragama, serta mampu menjaga persatuan dan kesatuan nasional. ${ }^{12}$

Dengan begitu, pendidikan Islam mengajarkan saling menghargai kepada sesama manusia yang merupakan makhluk ciptaan Allah, menghormati setiap bentuk pemikiran dan perilaku yang bertujuan menjaga dan melaksanakan kesalehan individu dan kesalehan sosial. Sebuah angan belaka apabila pendidikan Islam mengacuhkan prinsip dari kebaikan budi pekerti (akhlak). Nilai tersebut setidaknya mampu memberikan pandangan terhadap berkembangnya pendidikan Islam, memberikan ruang kepada peserta didik menghayati, memahami, serta mengimplementasikan dalam kehidupan sehari-hari untuk menghadirkan keindahan yang dinamis. ${ }^{13}$

Pendidikan Islam sendiri diartikan sebagai proses pembinaan dan bimbingan luar dalam dalam dari diri manusia berdasarkan aturan Islam yang bermuara pada terwujudnya kepribadian terbaik yang sesuai dengan ajaran Agama Islam. Selain itu, pendidikan Islam merupakan proses bimbingan terhadap perkembangan jasmani dan ruhani sesuai dengan ajaran Islam yang kaya akan makna mengarahkan, mengajarkan, melatih, mengasuh, serta mengawasi sesuai dengan ajaran Islam. Mengutip tulisan Bawani, ada beberapa hal pokok yang urgen dalam pendidilan Islam. Pertama, menyeimbangkan pengembangan potensi jasmani dan ruhani. Kedua, segala sesuatu yang dilakukan dalam pengembangan potensi tersebut, harus merujuk pada Alqur'an dan Hadist. Ketiga, tujuannya adalah perwujudan anak didik yang memiliki kepribadian mulia menurut Islam. ${ }^{14}$

Dengan begitu, pendidikan Islam dapat kita maknai sebagai suatu proses yang dilakukan seorang pendidik terhadap peserta didik, dengan mengedepankan serta menyeimbangkan kebutuhan jasmani dan ruhani yang merujuk pada Alqur'an dan Hadist. Demi terwujudnya peserta didik yang memiliki kepribadian terbaik menurut Islam. Pendidik tidak sematamata menyampaikan saja, namun harus mampu membina, mengarahkan, mengajarkan, serta mampu menjadi suri tauladan bagi peserta didik.

12 Muhaimin, Arab Baru Pengembangan Pendidikan Islam: Pemberdayaan, Pengembangan Kurikulum, Hingga Redefinisi Islamisasi Pengetahuan, (Bandung: Yayasan Nuansa Cendikia, 2003), hlm. 60

13 Faisol, Gusdur dan Pendidikan Islam: Upaya Mengembalikan Esensi Pendidikan di Era Global, (Yogyakarta-Ruzz Media, 2011), hlm. 40

14 As'aril Muhajir, Ilmu Pendidikan Perspektif Kontekstual (Yogyakarta:Ar-Ruzz Media,2011 ), hlm. 84 


\section{Tujuan Pendidikan dalam Islam}

Merujuk kembali pada definisi dari pendidikan Islam, yakni sebuah usaha dalam mengembangkan semua kemampuan peserta didik secara optimal, mulai dari jasmani, rohani, hingga akhlakul karimah. Sebuah proses pendidikan yang tidak memiliki tujuan yang jelas dan target yang pasti, hanya akan menjadi sebuah ketidakpastian dalam prosesnya. Dengan kata lain, muaranya adalah menjadikan peserta didik menuju kepribadian yang insan paripurna dengan pondasi peserta didik yang beriman dan kaya akan ilmu pengetahuan. Penanaman nilai-nilai ke-Islaman harus dilakukan secara konsisten, demi meraih tujuan seperti yang diharapkan.

Idealitas dalam tujuan pendidikan Islam yang memiliki nilai-nilai keIslaman harus diraih melalui proses pendidikan secara bertahap. Oleh karenanya, tujuan pendidikan Islam merupakan cermin nilai ke-Islaman yang harus diwujudkan dalam kepribadian peserta didik. Kepribadian yang beriman dan bertaqwa, berilmu, memiliki kreatifitas, kemandirian, dan pribadi yang bertanggung jawab setidaknya menjadi beberapa capaian dari perwujudan nilai-nilai ke-Islaman. Sebagaimana firman Allah dalam Q.S AlAn'am 162:

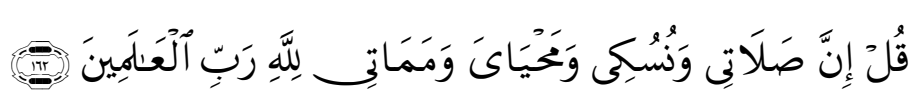

Katakanlah: Sesungguhnya sembahyangku, ibadatku, hidupku dan matiku hanyalah untuk Allah, Tuhan semesta alam. ${ }^{15}$

Berhubungan dengan tujuan dari pendidikan Islam, Muhammad Athiyyah Al-Abrasyi memberikan pandangan yakni: ${ }^{16}$

a. Mewujudkan proses pembentukan akhlak yang mulia;

b. Dalam rangka mempersiapkan kehidupan dunia dan akhirat;

c. Persiapan memperoleh rezeki dan memelihara segi-segi kemanfaatan;

d. Scientific spirit dalam proses belajar serta rasa ingin tahu dalam mengkaji ilmu sekadar sebagai ilmu;

15 Al-Qur an dan Terjemahannya Dilengkapi Kajian Ushul Fighi, (Jakarta: Departemen Agama, 2007).

16 M. Athiyah al-Abrasyi, Dasar-Dasar Pokok Pendidikan Islam, Terj (Jakarta: Bulan Bintang, 1970) hlm. 1-4. 
e. Dalam menjalani proses kehidupan, mampu mengetahui beberapa profesi tertentu agar mampu mencari rezeki sembari menjaga ibadah dan nilai ke-Islaman.

Tujuan pendidikan Islam merupakan proses mengembangkan cara berpikir dan pikiran manusia, mengatur tingkah laku, serta perasaan yang bertujuan untuk mengimplementasikan ketaatan dan penghambaan kepada Allah dalam kehidupan sebagai manusia di lingkungan masyarakat, bangsa, dan Negara. ${ }^{17}$ Kemudian, tujuan pendidikan seharusnya memberikan dampak pertumbuhan pribadi yang total pada manusia secara adil, dengan melakukan latihan spiritual, intelektual, rasional, rasa, dan kepekaan. Oleh karenanya, pendidikan harus mampu menyediakan jalan. ${ }^{18}$

Kesimpulan yang dapat kita ambil mengenai tujuan pendidikan Islam yakni menjadikan manusia sebagai pribadi yang soleh sebagai Abdullah, memiliki ketaatan beribadah dan nilai keimanan yang penuh keikhlasan, selalu berusaha menjaga perbuatan, ucapan dan tindakan, menjalankan seluruh yang diperintahkan Allah serta selalu berusaha menjauhi larangan-Nya. Hal tersebut dapat diperoleh melalui proses bimbingan, pengarahan, penguatan, pembiasaan, serta tuntunan seorang pendidik.

\section{Kajian Konseptual Pendidikan Humanis Religius}

Manusia merupakan makhluk ciptaan Tuhan yang memiliki ragam potensi yang tidak dimiliki makhluk ciptaan Allah yang lain. Manusia bisa saja disamakan dengan binatang, bahkan derajatnya lebih rendah daripada binatang bilamana kehidupan yang dijalani hanya mendahulukan nafsu dan menggunakan sifat-sifat binatang. Sebaliknya, manusia mampu berada diposisi yang mulia diatas malaikat apabila mampu melaksanakan tugas sebagai Abdullah dan Khalifatullah dalam kehidupan di dunia. Dengan begitu, pendidikan Islam seyogyanya harus melihat manusia Khalifah Fil Ardl, manusia yang mampu dibimbing, manusia yang mampu diarahkan,

17 Abd. Ar-Rahman an-Nawawi, Prinsip-Prinsip dan Metode Pendidikean Islam dalam Keluarga di Sekolah dan Masyarakat, Terj. Herry Noer Ali (Bandung, Diponegoro, 1989) hlm. 162. Lihat juga Haryanto Al-Fandi, Desain Pembelajaran yang Demokratis dan Humanis (Yogyakarta: Ar-Ruzz Media, 2011), hlm. 146

18 Azumardy Azra, Pendidikan Islam: Tradisi dan Modernisasi Menuju Milenium Baru, (Jakarta: Logos Wacana Ilmu, 1999) hlm. 57. Lihat juga Haryanto Al-Fandi, Desain Pembelajaran yang Demokratis dan Humanis (Yogyakarta: Ar-Ruzz Media, 2011), hlm. 148 
manusia yang memiliki keimanan, manusia yang bermoral, serta manusia yang berpengetahuan luas. ${ }^{19}$ Abdurrahman Mas'ud menyatakan bahwa:

'Nilai agama merupakan sesuatu yang dipandang memiliki nilai dan memiliki manfaat dalam perspektif agama. Nilai agama merupakan seluruh usaha yang memilik tujuan membina hati nurani, mengarah pada peserta didik agar memiliki kepekaan dan penghayatan atas nilai-nilai yang luhur dalam kehidupannya. Dalam perspektif Islam, tataran nilai yang harus ditempah dalam pribadi siswa secara keseluruhan. Seperti norma hukum, norma akhlak, dan lain sebagainya. Norma tersebut sebenarnya diperlukan pendidik dan peserta didik untuk memperjelas pedoman operatif dalam proses pendidikan yang diselenggarakan." 20

Sebuah proses pendidikan, tidak semata-mata menekankan pada proses kecerdasan kognitif saja, sementara afektif dan psikomotorik bukan menjadi sebuah prioritas dalam pendidikan. Sehingga, kecenderungan terhadap pengembangan utuh dari peserta didik tidak berjalan secara optimal. Pendidikan Islam yang seharusnya mampu menghadirkan wajah dan kepribadian yang memiliki muatan nilai ke-Islaman, justru jauh dari yang sebenarnya diharapkan. Dampak dari hanya mengedepankan satu aspek kecerdasan adalah melemahkan peserta didik yang seharusnya mendapatkan bimbingan, arahan, nasehat, penguatan, serta pengayoman dari seorang pendidik.

Humanisme dalam pendidikan merupakan proses pendidikan yang lebih memprioritaskan potensi manusia sebagai makhluk sosial dan makhluk berketuhanan. Manusia merupakan individu yang telah diberikan kesempatan oleh Allah untuk mengembangkan potensi tersebut. ${ }^{21}$ Selain itu, pendidikan humanis merupakan implementasi pendidikan yang melihat manusia sebagai suatu kesatuan yang utuh, melihat manusia sebagai

19 Haryanto Al-Fandi, Desain Pembelajaran yang Demokratis dan Humanis (Yogyakarta: ArRuzz Media, 2011), hlm. 182

20 Pernyataan Abdurrahman Mas'ud, disampaikan dalam kuliah Guru besar Tamu: Prof. Dr. Abdurrahman Mas'ud di Gedung Serba Guna STAIN Jurai Siwo Metro Lampung, kamis 20 Juni 2013. Lihat Juga Ida Nurjanah, Paradigma Humanisme Religius Pendidikan Islam: Telaah Atas Pemikiran Abdurrahman Mas'ud, Jumal MISYKAT Vol. 03 No. 01 edisi Juni 2018, hlm. 156

21 Abdurrahman Mas'ud, Menggagas Format Pendidikan Nondikotomik: Humanisme Religius Sebagai Paradigma Pendidikan Islam,(Yogyakarta: Gama Media, 2002) hlm. 15 
manusia sebagai ciptaan Allah dengan fitrahnya untuk dikembangkan secara maksimal. ${ }^{22}$ Pendidikan humanis sangat menghargai harkat dan martabat setiap peserta didik, termasuk segala sesuatu yang ada pada diri peserta didik. Pendidikan humanis memberikan ruang merdeka secara penuh kepada peserta didik untuk mengembangkan potensinya.

Pada intinya, pendidikan humanis memuat karakteristik sebagai berikut. Pertama, menghargai dan mengembangkan potensi manusia secara utuh. Kedua. Mengembangkan seluruh aspek kecerdasan manusia. Ketiga, pendidikan yang memiliki interaksi antara pendidik dan peserta didik. Keempat, pendidikan yang penuh penghormatan dan penghargaan. Kelima, pendidikan yang memiliki kepedulian terhadap peserta didik. Keenam, pendidikan yang mengeksplor kemampuan peserta didik serta memberi ruang merdeka kepada mereka. Ketujuh, pendidikan yang mampu mengubah perilaku peserta didik. Kedelapan, pendidikan yang mengutamakan proses ketimbang hasil. ${ }^{23}$

Kemudian, untuk pendidikan religius sendiri merupakan pendidikan yang mengajarkan nilai-nilai keagaaman, apapun agamanya. Pendidikan ini kaya akan nilai-nilai moral. Hal ini akan sejalan dengan falsafah dari negara besar kita Indonesia, yakni Pancasila. Tak hanya itu, pendidikan religius juga mengajarkann bagaimana menghargai nilai -nilai dasar kemanusiaan. Akan sangat disayangkan apabila dalam pelaksanaan pendidikan yang katanya religius namun tidak mengindahkan nilai dari kemanusiaan itu sendiri. ${ }^{24}$

Dalam ruang lingkup Indonesia, humanis religius ${ }^{25}$ merupakan humanisme yang berisikan nilai-nilai suci ajaran suatu agama. Akan ada

22 Baharudin dan Muh. Makin, Pendidikan Humanistik: teori, konsep, dan aplikasi praksis dalam dunia pendidikan, (Yogyakarta: Ar-Ruzz Media, 2009) hlm. 23

23 Haryanto Al-Fandi, Desain Pembelajaran...hlm. 197-198

24 Hibana, A. Sodiq, Sutrisno, Pengembangan Pendidikan Humanis Religius di Madrasah, Jurnal Pembangunan Pendidikan: Fondasi dan Aplikasi Vol. 3 No. 1 Juni 2015, hlm. 21

25 Istilah "pendidikan humanistik-Islami”" mencakup dua konsep pendidikan yang ingin diintegrasikan, yakni pendidikan humanistik dan pendidikan Islam. Dalam pengintegrasian dua konsep pendidikan ini dimaksudkan juga untuk mengurangi kelemahannya. Pendidikan humanistik yang menekankan kemerdekaan individu diintegrasikan dengan pendidikan religius (Islam) agar dapat membangun kehidupan sosial yang menjamin kemerdekaan dengan tidak meninggalkan nilai ajaran agama. Kemerdekaan individu dalam pendidikan humanistik-Islami dibatasi oleh nilai ajaran Islam. Nilai-nilai agama diharapkan menjadi pendorong perwujudan nilai-nilai kemanusiaan. Pemisahan antara kedua konsep tersebut akan menyebabkan tidak terwujudnya nilai-nilai humanisme Islam dalam sistem pendidikan. Pendidikan humanistik 
keterkaitan dan hubungan antara pandangan terhadap manusia sebagai makhluk ciptaan Allah yang harus dikembangkan seluruh potensinya, dan pengembangan yang akan dilakukan tidak kontra dengan ajaran agama yang menjadi identitas bangsa Indonesia. ${ }^{26}$ Berdasarkan pandangan tersebut, implementasi dalam proses pendidikan harus berdasarkan pada pengembangan potensi-potensi manusia. Menurut pandangan Islam, manusia dianggap sebagai makhluk yang memiliki akal. Oleh karena itu, pendidikan Islam akan berorientasi pada pembentukan manusia-manusia yang sesuai dengan kodratnya. ${ }^{27}$

Manusia merupakan makhluk berjiwa (cipta, rasa, karsa), oleh karena itu, pendidikan harus bermuara pada bagaimana upaya mengembangkan potensi berpikir, nalar, serta rasio manusia, sehingga menjadi pribadi yang cerdas. Manusia harus mampu memiliki ilmu pengetahuan dan mampu menguasai dan memahami teknologi yang setiap harinya berkembang. Manusia perlu mendapatkan proses pendidikan yang baik, agar berdampak pula pada moral dan karakter yang baik. ${ }^{28}$

Dengan demikian, pendidikan humanis religius dapat diartikan sebagai sebuah proses pembelajaran yang menekankan pada ruang kemerdekaan seorang peserta didik, dengan tidak mengesampingkan muatan nilai keagamaan. Konsep memanusiakan manusia dapat diinterpretasikan melalui pengembangan pengetahuan, keterampilan peserta

menjadi pengembangan fitrah manusia. Islam memandang fitrah bukan tabula rasa (manusia tanpa bakat, bekal, atau kemampuan). Fitrah merupakan pemberian dari Allah yang berisi potensi baik dan potensi buruk. Potensi ini akan berkembang dan teraktualisasi dalam kehidupan tergantung pada pendidikan dan budaya. Kalau manusia tepat mengembangkan potensi positif akan dekat dengan sifat ilahiah. Sebaliknya bila yang berkembang itu potensi jahatya, manusia akan bisa lebih jahat daripada setan. Tugas pendidikan adalah mengurangi atau bahkan menghilangkan potensi jahat dan mengembangkan potensi baiknya. Pendidikan humanistik bertolak dari fitrah manusia dalam mengaplikasikan, mengembangakan, dan menanamkan nilai-nilai universal dalam diri manusia sehingga menjadi manusia yang sesungguhnya.

26 Nurkholis, "Reorientasi Dan Implementasi Pendidikan Humanis Religius," dalam, Ta aellum, 1 (Juni, 2010), hlm. 8. Lihat Juga Ida Nurjanah, Paradigma Humanisme Religius Pendidikan Islam: Telaah Atas Pemikiran Abdurrahman Mas'ud, Jurnal MISYKAT Vol. 03 No. 01 edisi Juni 2018, hlm. 156

27 A. Syafie ${ }^{e i}$ Ma"earif, Pendidikan Islam di Indonesia: Antara Cita Dan Fakta (Yogyakarta: Tiara Wacana Yogya, 1991), 29-31. Lihat Juga Ida Nurjanah, Paradigma Humanisme Religius Pendidikan Islam: Telaah Atas Pemikiran Abdurrahman Mas'ud, Jurnal MISYKAT Vol. 03 No. 01 edisi Juni 2018, hlm. 156

28 Rukiyati, Percikan Pemikiran Pendidikan Humanis Religius, Jurnal HUMANIKA: Kajian Ilmiah Mata Kuliab Umum Vol. 13 NO. 1 Tahun 2013 hlm. 6 
didik, etika dan moral, serta pribadi peserta didik yang insan paripurna. Berupaya untuk melakukan secara terus menerus, tanpa memilah dan memilih setiap peserta didik untuk diajarkan, karena hal tersebut akan berdampak pada kondisi psikologi peserta didik.

\section{Urgensi Pendidikan Humanis Religius pada Pendidikan Dasar Islam}

Konsep pendidikan humanis religius menjadi begitu penting untuk dikembangkan dalam pendidikan Islam, khususnya pendidikan dasar. Melihat fenomena-fenomena peserta didik pada tingkat dasar yang perlu mendapatkan perhatian khusus, dikarenakan perkembangan teknologi yang begitu pesat setiap waktunya, memberikan ruang merdeka namun jauh dari pribadi-pribadi yang memiliki moral dan etika baik di lingkungan sekolah maupun masyarakat. Pentingnya mengembalikan dunia anak pada kehidupan mereka yang sebenarnya sembari memberikan penguatan dan pembiasaan melalui nilai-nilai religiusitas.

Pendidikan humanis religius menjadi penting untuk pendidikan dasar Islam karena pada dasarnya berorientasi pada pengembangan potensi peserta didik dan kemerdekaan individunya. Peserta didik akan memiliki ruang bebas dalam peningkatan dan pengembangan kemampuan melalui proses bimbingan, pengarahan, penanaman, serta penguatan yang dilakukan seorang pendidikan dengan memasukkan muatan nilai keagamaan dan keberagaman. Proses pembelajaran yang tidak pernah melemahkan peserta didik, pembelajaran yang lebih memprioritaskan pemberian reward daripada hukuman, serta mengayomi seluruh peserta didik dengan menyamakan persepsi hak-hak dan kewajiban peserta didik di dalam kelas.

Pendidikan humanis religius dipercaya mampu mengembalikan peran sekaligus fungsi manusia kepada fitrahnya sebagai sebaik-baiknya makhluk (khairu ummah). Maka manusia yang "manusiawi" yang dihasilkan diharapkan dapat mengembangkan dan membentuk manusia berpikir, berasa, berkemauan, dan bertindak sesuai dengan nilai-nilai luhur kemanusiaan. Nilai-nilai luhur kemanusiaan tersebut adalah dapat mengganti sifat individualistik, egoistik, dan egosentrik dengan sifat kasih sayang kepada sesama manusia. Selain itu, tertanamnya sikap saling 
menghormati dan dihormati, sifat ingin memberi dan menerima, sifat saling menolong, serta sikap menghargai suatu perbedaan. ${ }^{29}$

\section{KESIMPULAN}

Semua makhluk yang ada di seluruh planet ini merupakan ciptaan Allah, termasuk manusia yang merupakan makhluk ciptaan paling sempurna. Allah bekali manusia akal, kemampuan berpikir, serta memiliki perasaan. Kesempurnaan manusia bukan berarti menjadi kesombongan dan keangkuhan sebagai penghuni bumi untuk semena-mena kepada setiap makhluk yang ada. Berperilaku merendahkan, bersikap melemahkan, serta berbuat segala sesuatu tanpa aturan bukan potensi yang harus dipelihara dan mendarah daging dalam diri manusia.

Pendidikan humanis religius menjadi wadah bagi pendidik dalam mengarahkan, membimbing, dan membina peserta didik agar memiliki moral dan perilaku yang sesuai dengan nilai ke-Islaman. Menempatkan posisi pembelajaran yang memanusiakan manusia, penghargaan penuh terhadap potensi peserta didik, serta memberikan ruang bebas kepada peserta didik untuk mengembangkan kemampuan yang dimiliki. Akan tetapi, kebebasan tersebut akan diintegrasikan dengan penanaman nilai-nilai humanis religius agar peserta didik tetap memiliki karakter dan kepribadian yang sesuai dengan nilai keIslaman.

\section{DAFTAR PUSTAKA}

Al-Qur'an dan Terjemahannya Dilengkapi Kajian Ushul Fighi, (Jakarta: Departemen Agama, 2007).

Al-Abrasyi, M. Athiyah Dasar-Dasar Pokok Pendidikan Islam, Terj (Jakarta: Bulan Bintang, 1970)

Al-Fandi, Haryanto Desain Pembelajaran yang Demokratis dan Humanis, (Yogyakarta, Ar-Ruzz Media, 2011)

An-Nawawi, Abd. Ar-Rahman Prinsip-Prinsip dan Metode Pendidikan Islam dalam Keluarga di Sekolah dan Masyarakat, Terj. Herry Noer Ali (Bandung, Diponegoro, 1989)

Azra, Azumardy Pendidikan Islam: Tradisi dan Modernisasi Menuju Milenium Baru, (Jakarta: Logos Wacana Ilmu, 1999) 
192 | AR-RIAYAH : Jurnal Pendidikan Dasar vol. 3, no. 2, 2019

A. Sodiq Hibana, Sutrisno, Pengembangan Pendidikan Humanis Religius di Madrasah, Jurnal Pembangunan Pendidikan: Fondasi dan Aplikasi Vol. 3 No. 1 Juni 2015

Faisol, Gusdur dan Pendidikan Islam: Upaya Mengembalikan Esensi Pendidikan di Era Global, (Yogyakarta-Ruzz Media, 2011)

Jusuf Mudzakkir, Abdul Mujib, Ilmu Pendidikan Islam: Pengantar ke Arah Ilmu Pendidikan Islam, (Jakarta: Kencana, 2006)

Makin Muh., Baharudin, Pendidikan Humanistik: teori, konsep, dan aplikasi praksis dalam dunia pendidikan, (Yogyakarta: Ar-Ruzz Media, 2009)

Ma'arif A. Syafi'i, Pendidikan Islam di Indonesia: Antara Cita Dan Fakta (Yogyakarta: Tiara Wacana Yogya, 1991)

Mas'ud, Abdurrahman Menggagas Format Pendidikan Nondikotomik: Humanisme Religius Sebagai Paradigma Pendidikan Islam,(Yogyakarta: Gama Media, 2002)

Muhaimin, Arab Baru Pengembangan Pendidikan Islam: Pemberdayaan, Pengembangan Kurikulum, Hingga Redefinisi Islamisasi Pengetahuan, (Bandung: Yayasan Nuansa Cendikia, 2003)

Muhajir, As'aril Ilmu Pendidikan Perspektif Kontekstual (Yogyakarta:Ar-Ruzz Media,2011)

Nata Abuddin, Filsafat Pendidikan Islam, (Jakarta: Gaya Media Pratama, 2005)

Nurjanah Ida, Paradigma Humanisme Religius Pendidikan Islam: Telaah Atas Pemikiran Abdurrahman Mas'ud, Jurnal MISYKAT Vol. 03 No. 01 edisi Juni 2018

Nurkholis, "Reorientasi Dan Implementasi Pendidikan Humanis Religius," dalam, Ta aellum, 1 (Juni, 2010)

Rukiyati, Percikan Pemikiran Pendidikan Humanis Religius, Jurnal HUMANIKA: Kajian Imiah Mata Kuliab Umum Vol. 13 NO. 1 Tahun 2013

Saehuddin, Ahmad Izzan dan Tafsir Pendidikan: Studi Ayat-Ayat Berdimensi Pendidikan, (Jakarta: Pustaka Aufa Media, 2012)

Sugiharto, Bambang (ed), Humanisme dan Humaniora: Relevansinya bagi Pendidikan, (Yogyakarta: Jala Sutra, 2008) 